\title{
Dronology and 3D Printing as a Catalyst for International Trade in Industry 4.0.
}

\author{
ILONA DUMANSKA $^{1 *}$, DMYTRO VASYLKIVSKYI ${ }^{2 *}$, IGOR ZHURBA ${ }^{3 *}$, \\ YANA PUKHALSKA $^{4 *}$, OLHA MATVIIETS ${ }^{5 *}$, ANDRIY GONCHARUK ${ }^{6 *}$ \\ 1, 2, 4, 5 Department of International Economic Relations, Khmelnytskyi National \\ University, 11, Instytutska street, UKRAINE \\ ${ }^{3}$ Department of International Relations and Tourism, Khmelnytskyi National University, \\ 11, Instytutska street, UKRAINE \\ ${ }^{6}$ Department of Economics, Management and Administration, Khmelnytskyi National \\ University, 11, Instytutska street, UKRAINE
}

\begin{abstract}
The article reveals the content of Industry 4.0 technologies in the subsystems of international trade. The destructive type of innovations of the fourth industrial revolution on traditional spheres of trade is defined. The types of modern innovations related to the technologies of Industry 4.0 and form competitive advantages in successful global brands are identified and characterized, they are reviewed for the presence of common features inherent in its technologies and innovations in general. The influence of Industry 4.0 on the stages of introduction of the innovation process in international trade is analysed. It is established that at the stage of experimental implementation of innovations, omnichannel logistics, drones, and 3D printing have a high level of influence, which are trends in the miniaturization of the economy and the concept of «smart enterprise». An analysis of the impact of the trend of changes from Industry 4.0 innovations in international trade through the impact on consumer behavior and the functioning of business models of enterprises. The expediency of introduction of drones in the aspect of expansion of sales channels and receipt of goods on the basis of the omnichannel approach of increase of volumes of the international trade is proved. Existing and perspective spheres of application of drone logistics are analysed. A positive effect in terms of optimizing the cost of maintaining employees through the use of drones on the example of warehousing and fast delivery of goods to order. The problem of large- scale introduction of drones to exacerbate the issue of replacing workers in entire industries with artificial intelligence and the need to learn new professions is outlined. The influence of additive production on international trade by introduction of 3D printing technology is analysed, the spheres of its application and consequences of introduction are defined. The reality of the scenario forecast of development of 3D printing and its influence on subsystems of the international trade, chains of delivery of the goods, formation of stocks of raw materials and materials is considered. The possible consequences of the application of 3D printing technology for the field of intellectual property are described. It is proved that the key catalysts of Industry 4.0 at the level of international trade are innovations in the form of attracting drones to logistics supply and marketing systems and inventory optimization by expanding the scope of $3 \mathrm{D}$ reproduction techniques.
\end{abstract}

Key-Words: - Industry 4.0, technology, innovation, international trade, logistics, drones, dronology, 3D printing, omnichannel, additive manufacturing.

Received: December 10, 2020. Revised: June 13, 2021. Accepted: July 2, 2021. Published: July 15, 2021.

\section{Introduction}

Today, there is a demand from business for a deep understanding and analysis of the opportunities that open up in international trade due to the emergence and development of new technologies based on the global diffusion of Industry 4.0 assets. Well-known global corporations such as Amazon,
DHL, UPS, Adidas are investing in research innovations in the logistics component of international trade and the development of such areas as e-commerce, in particular, in terms of finding ways to use $3 \mathrm{D}$ printing technology and unmanned vehicles.

Scientific views on the concept of «Industry 4.0» differ due to the focus on certain features of 
digitalization of international trade and its transition to the online segment. According to experts, online sales will increase by $20 \%$ this year, and the total amount of trade will reach $\$ 1.5$ trillion. Extending to new markets, the element of the fourth per mille resolution leaves no choice to retailers and trading platforms, except anywhere and at any time to be ready to meet customer demands, forming a new approach in international trade - omnichannel.

McKinsey predicts [1] that in the future, autonomous vehicles and unmanned aerial vehicles, in particular, will deliver $78 \%$ of all items, with traditional delivery being only $20 \%$ and another $2 \%$ accounted for by courier. Trucks equipped with automatic driving system, unmanned aerial vehicles and robots will be the key to increasing last mile delivery options while maintaining high reliability and stock reproduction will take place at the customer's request on the day of order with minimization of inventory through 3D printing.

In this pursuit of the ideal operation of stores against the background of the globalization of international trade, the use of several channels of communication and decompensation of leftovers is crucial, as business success depends largely on the efficiency of the «last mile» system. It is this eponymous concept proposed by McKinsey that defines the mechanism for optimizing the system of transportation and warehousing, which in our publication is considered through the prism of key catalysts for international trade, which accelerate its development based on 3D printing and logistics using drones.

The ideas we will consider are just the beginning, but they can be useful for making optimal decisions, understanding the complexity of the «last mile problem» and developing an optimal scheme to overcome it in Industry 4.0 by reviewing the supply chain and inventory management system. compliance with modern consumer requirements for the purchase and delivery of goods based on tools such as drone logistics and 3D printing.

\section{Literature Review}

The theoretical basis for the transformation of all modern subsystems of international trade was the concept of Industry 4.0 or the fourth industrial revolution. At the same time, its essence, specificity, features and basic primary knowledge were formed at the level of the manufacturing sector of industry with a projection on the subsystems of international trade on the basis of a deductive approach.

Barreto L., Amaral A., Pereira T. [2] present a study of the impact of Industry 4.0 on industry and production processes, identify a new species sectors of the economy - «Industry 4.0», but do not detail its impact on logistics or any other subsystem of international trade. Wollschlaeger M., Sauter T., Jasperneite $\mathrm{J}$ [3] support the concept of previous researchers on the development of Industry 4.0, but their research is already becoming closer to the issue of international trade. In particular, their publication draws attention to the communication aspect of the introduction of Industry 4.0 innovations in the age of the Internet of Things.

A number of scientists, including Josef Börcsök, Michael Schwarz, Muhammad Ikram Hafiz, Mohamed Abdelawwad, Ahmed Alsuleiman [4], are focusing on such achievements of the fourth industrial revolution as wireless applications in the security system of devices running on chips. Continuation of such research was the work of Elda Cina, Hiba Tabbara, Esmerald Aliaj [5] on data protection during digitalization processes. These studies are relevant, but to a greater extent reflect the technological aspect of «Industry 4.0» in the segment of cybersecurity of information systems, but do not fully disclose the implementation of Industry 4.0 in international trade. The authors of the paper have improved the scientific and methodological approach to modeling the potential level, which involves defining the potential as a generalized coefficient of desirability, which depends on the financial, personnel, innovation potential and energy saving potential [6].

Duong Oesterreich T., Teuteberg F. [7] and Scalabre O. [8] consider the effects of digitization and automation in the context of Industry 4.0, for the first time highlighting the role of innovations such as drones and $3 \mathrm{D}$ printing in the construction industry and identify their positive impact on profitability.

Possibilities of sustainable production in industry under the conditions of Industry 4.0. through the prism of the introduction of drone logistics and optimization of industrial stocks is succinctly considered in the works of Stock T., Seliger G [9] and Geissbauer R., Schrauf S., Koch V., Kuge S. [10].

Clever design and production management for effective mass adaptation of the concept of Industry 4.0 in international trade is considered by Zawadzki P., Zywicki K. [11], the impact of industrial wireless networks in the context of Industry 4.0 on technological innovation is studied in Xiaomin $\mathrm{Fu}$, Wios Li, Anthanasios V. Vasilakos [12] and Gilchrist A. [13]. At the same time, the study of Industry 4.0 technologies in the works of these authors is important only in determining the generalizing catalytic impact of innovation on the 
development of international trade, but lacks analysis of the use of drone logistics and 3D printing as Industry 4.0 innovation.

The global context of the strategy of cooperation with international partners in the field of trade in the context of Industry 4.0. analyze Kagermann H., Anderl R., Gausemeier J., Schuh G., Wahlster W. [14], determining the prospects of 3D printing and other technologies of Industry 4.0, while the aspect of optimization of delivery and its acceleration in time by drones and robotics remain little studied.

The future of productivity and growth in manufacturing is influenced by Industry 4.0. on the positive and negative sides, they were also analyzed at the level of practicing specialists of international consulting corporations. Among them are experts from the Boston Consulting Group: Rubmann, M., Lorenz, M., Gerbert, P., Waldner, M. et. al. [15] and a group of researchers from McKinsey [1], who in their work form the primary data on scenarios for the future development of drone science and promising areas of involvement of the printing press in certain areas. More detailed research and scenario design development is indicated by Innovative Technology Industry 4.0. formed in the publications of Hermann M., Pentek T., Otto B. [16].

The lack of a comprehensive approach to the analysis of logistics innovations, in particular dronebased logistics and 3D printing against the background of globalist priorities of international trade, generated by the IV Industrial Revolution necessitates recourse to separate research in drone logistics and 3D printing to form a single research base.

In the context of the study of drone logistics, we note that valuable in the scientific sense are studies of the problems of formation of drones on the basis of primary studies of the use of drones conducted by Chabot D. [17]. More meaningful and conceptually relevant Industry 4.0 research. in the field of international trade there are scientific works and practical developments of such well-known scientists and inventors in the field of drone logistics as Roca-Riu M., Menendez M. [18], Bass, J. [19], Petrunya Y. and Pasichnyk T. [20], Figliozzi, M., Tucker, C., Polikakhina, P. [21], Wang K. [22], Winkelhaus S., Grosse E. [23]. Extensive studies of drone logistics in the subsystem of international trade warehousing are presented in the works of Wawrla L., Maghazei O., Netland T. [24] and Cleland-Huang, Jane \& Vierhauser, Michael \& Bayley Sean [25].

Equally relevant are studies driven by the need for scientific understanding of significant socioeconomic opportunities, changes and the impact of
3D printing and the need to develop this area of activity in international trade, which are concentrated in the works of Eckstein Maya M. [26], Abeliansky Ana L., Martínez-Zarzoso Imnaculada, Prettner K. [27], Leering R. [28], Moreau C. [29].

\section{Problem Formulation}

A systematic review of the above research by scientists, practitioners and analysts of leading consulting corporations identifies the lack of thorough research to identify the impact on international trade of Industry 4.0 innovations such as drone logistics and 3D printing, based on indepth analysis of global trends and international trends.

Accordingly, in today's conditions, the field of drone logistics should be considered as a separate type of logistics subsystem in the field of trade on a par with its other components and identify aspects of new professions and competencies in the context of globalization and integration of successful drone experience in developed countries.

Equally urgent is the need to form scientific and practical approaches to the study of $3 \mathrm{D}$ printing as a compensatory model of stocks in international trade and mechanisms for its use to ensure copyright in intellectual property.

Implementation of the presented problematic aspects, according to the authors of this publication, will provide a more complete and comprehensive reflection of the main parameters and characteristics of the globalization trends of Industry 4.0 in supply and marketing chains, employment in new areas, optimization of inventory structure against the influence of such catalysts trade as drone logistics and $3 \mathrm{D}$ printing.

\section{The Research Methods}

In order to achieve the objectives of the study to identify the catalytic effect on international trade of such Industry innovations 4.0 as $3 \mathrm{D}$ printing and drone logistics, a combination of general and special methods is used to ensure the logic, reliability and validity of the study. In particular, such general scientific methods as scientific abstraction, analysis, synthesis, deduction, induction, comparison, grouping and generalization are implemented in the study through a system of economic parameters and indicators of international trade [30] in Industry 4.0, based on analysis of the effectiveness of 3D printing and drone logistics in all its subsystems. The definition of the essence of the categories Industry 4.0, drone logistics, 3D printing and implementation 
of the evolution of their formation is carried out on the basis of scientific abstraction and historical method. Study of the effects of technologies and innovations of Industry 4.0 on international trade and their compliance with the typology of the fourth industrial revolution; characterization of key innovations and competitive advantages gained from their implementation by successful global brands is implemented using methods of analysis, synthesis, deduction and induction. The method of comparison reflected the expectations of consumers regarding the speed of delivery by drones and revealed the prospects of expanding sales channels and receiving goods in the optimized time with the use of drones and without their use in the delivery of goods and warehousing; the advantages of manufacturing parts on a $3 \mathrm{D}$ printer compared to the basic production are established.

To determine the impact of Industry 4.0 on the stages of implementation of the innovation process in international trade, a causal analysis was used, which identified the impact of additive manufacturing on international trade based on 3D printing and drone science in the omnichannel approach. The grouping and generalization methods provided a presentation of the results of the impact of changes in trends from Industry 4.0 innovations. in international trade through the impact on consumer behavior and the functioning of business models of enterprises specializing in international trade, the presentation of applications and the consequences of the introduction of threedimensional printing and drone logistics. The implementation of systems analysis provided a study of changes in the penetration of technologies in Industry 4.0. in the subsystems of international trade by their types, catalysing the effect of drone logistics on international trade and the impact of 3D printing technology on changing the models of existing supply chains in the international trade system. Thanks to the graphic method, a conditional scenario of the impact of 3D printing on world production was presented; statistical comparison - to study the impact of drone logistics and 3D printing as a destructive innovation of Industry 4.0 on international trade. In the conclusions of the publication on the optimization of the principles of international trade in Industry 4.0 on the basis of the concept of «Last Mile» McKinsey under the influence of drone and 3D printing was introduced abstract-logical and theoretical generalization, which provided a comprehensive reproduction of the study.

\section{Problem Solution}

So far, the fourth industrial revolution, better known as «Industry 4.0», has reached the segment of international trade, which has had a reviving effect. It takes its name from a 2011 initiative led by businessmen, politicians and scientists who identified it as a means of increasing the competitiveness of Germany's manufacturing industry through enhanced integration of «cyberphysical systems» into factory processes and was voiced in Hanover at the Industrial Fair. In general, the essence of Industry 4.0 is to create integrated chains of innovation: from creative ideas to new products and services by implementing such basic elements of innovation policy as increasing competitiveness through the priority of the value of creativity and quality of life; strengthening cooperation and supporting implementation through network development and information transfer; creating a favourable infrastructure for development and creativity directly and indirectly through the digitalization of society.

Today, brands that are evolving through digital technology are extremely fiercely competing with companies operating in traditional industries. At the last World Economic Forum in Davos (Switzerland), held from 22 to 25 January 2019, the main topic for discussion «Globalization 4.0: the formation of global architecture in the era of the fourth industrial revolution» highlighted two main topics - global cooperation and change as a result of the high-tech digital revolution and presented the Brand Finance Global 500 report with the results of the evaluation of five hundred strong global brands with the highest value [31].

Table 1 presents the first in the ranking of Brand Finance Global 500 strongest growing global brands in 2019, highlights the key innovations of Industry 4.0 in their promotion, as well as competitive advantages.

It is worth noting that the key to their success is gaining a competitive advantage among others through the introduction of Industry 4.0 innovations. Brands such as Amazon, Apple, Google and Microsoft see Industry 4.0 as a tool to build economic potential, and for the past twenty years have been actively implementing and producing innovative developments themselves, thereby increasing their own competitiveness. As owners of market innovations, such companies gain a competitive advantage over other market players in the supply, distribution and sales segments through access to the largest and most accurate product base in the world and the ability to fully meet the needs of each individual customer in goods and services. 
Table 1. Characteristics of key innovations and competitive advantages of the strongest global brands

\begin{tabular}{|c|c|c|c|c|c|}
\hline Brand & $\begin{array}{l}\text { The value of } \\
\text { the brand in } \\
\text { 2020, billion } \\
\text { US dollars }\end{array}$ & $\begin{array}{c}\text { Value } \\
\text { increase, } \\
2020 / 2019 \\
\% \\
\end{array}$ & $\begin{array}{l}\text { Sphere of } \\
\text { activity }\end{array}$ & Key innovations & Competitive advantages \\
\hline Amazon & 187,905 & +24.6 & Online trade & $\begin{array}{l}\text { Echo voice control speaker, Web Services cloud } \\
\text { service, offline access from Amazon Go (retail } \\
\text { store without cash registers), integration with } \\
\text { financial sector companies JPMorgan and } \\
\text { Berkshire Hathaway } \\
\end{array}$ & $\begin{array}{c}\text { Access to the largest and most } \\
\text { accurate database of goods in the } \\
\text { world }\end{array}$ \\
\hline Apple & 153,634 & +5.0 & $\begin{array}{l}\text { Production of } \\
\text { software and } \\
\text { elite electronic } \\
\quad \text { devices }\end{array}$ & $\begin{array}{c}\text { In design, elegant interface; technological } \\
\text { innovations in the new models iPhone, MacBook, } \\
\text { Apple Watch (the world's first mobile processor } \\
\text { built on the 7th process, the world's first 3D facial } \\
\text { scanner for a smartphone, ECG scanner in the } \\
\text { Apple Watch Series 4); expansion of iCloud, } \\
\text { iTunes, AppStore, Apple Pay and Apple Music } \\
\text { services }\end{array}$ & $\begin{array}{c}\text { Access to the largest and most } \\
\text { accurate database of goods in the } \\
\text { world }\end{array}$ \\
\hline Google & 142,755 & +18.1 & $\begin{array}{c}\text { Online services } \\
\text { (Gmail, Google } \\
\text { Maps, Google } \\
\text { Docs, YouTube), } \\
\text { Android software } \\
\text { and Chrome } \\
\text { browser } \\
\end{array}$ & $\begin{array}{l}\text { Google Home Voice Assistant, Virtual / } \\
\text { Augmented Reality Systems (Google Glass } \\
\text { Enterprise Edition), Google Cloud Platform } \\
\text { Cloud Service, Unmanned Technologies }\end{array}$ & $\begin{array}{c}\text { The greatest successes in the field of } \\
\text { machine learning and access to the } \\
\text { largest statistics on the requests of } \\
\text { both the entire public consciousness } \\
\text { and each individual }\end{array}$ \\
\hline Microsoft & 119,595 & +18.1 & $\begin{array}{c}\text { Software } \\
\text { production }\end{array}$ & \multicolumn{2}{|c|}{ Microsoft Azure cloud platform } \\
\hline
\end{tabular}

Source: finalized by the authors on the basis of [32]

Based on the above, we can state that Industry 4.0. is a global phenomenon that needs to adapt to changes in society based on innovative technologies. The «be yourself an innovator» rule creates added value for those businesses that are engaged in international trade.

The researcher notes that innovative technologies are already transforming the consumer sector and, accordingly, the retail sector in the international aspect. Among them are the following types of technologies [33]: omnichannel, retail in the Internet (e-tailing), mobile commerce (m-commerce), commerce on Facebook (f-commerce), cloud computing, augmented reality, drones, the Internet of Things, which become not only a service link, but also a means of choosing the most convenient sales channel.

As a result, the next report of Deloitte Global Powers of Retailing 2018 [34] examines global processes and identifies 5 global trends in the development of retail of these successful brands in the international aspect, which resonate with these or are formed under their influence:

1. Consumers increasingly value the impact of purchases on their lives and consumer experiences, rather than the number of things;

2. There is a so-called «economy of social networks", when the choice of purchase is influenced by the image created by a person in the networks, ie «personal brand»;

3 . There is a change in the formats of the culture of general consumption, which leads to the fact that when choosing goods, the buyer pays special attention to other people's opinions and key trends in the world;

4. Retail companies have to adapt to customer requirements and try to quickly form and execute orders in accordance with customer requests (fast shopping), as they seek to get the maximum service in the minimum time;

5. Lifestyle based on exponential technologies, such as artificial intelligence, roboti, is gaining momentum.

Thus, Industry 4.0, despite the decline in the cost of technology, modification and optimization of labor costs, increasing online sales of goods and their supply creates an opportunity to increase the value of the company, increasing competition by introducing innovations in all subsystems of trade, as demonstrated by such companies like Amazon, Apple, Google, Microsoft on the basis of testing with the subsequent development of $3 \mathrm{D}$ printing and drone logistics. At the same time, the key catalysts of Industry 4.0 at the level of international trade, not just retail, are innovations in the form of attracting drones to logistics supply and marketing systems and inventory optimization by expanding the scope of reproduction of things based on $3 \mathrm{D}$ printing.

\subsection{Industry 4.0 Technology in International Trade}

In order to determine which of the modern innovations are related to the technologies of 
Industry 4.0 , it is necessary to check them for the presence of common features inherent in its technologies and innovations in general. The features of the fourth industrial revolution (or «Industry 4.0») include the type of destructive innovations that are obtained and implemented in the value chain and aimed at such digitalization trends as digitalization, autonomization, transparency, mobility, modularization, networkcollaboration and socializing goods and processes [20].

According to Table 2 at the stage of experimental implementation of innovations in Industry 4.0.

Table 2. The impact of Industry 4.0 on the stages of implementation of the innovation process in international

\begin{tabular}{|c|c|c|c|}
\hline $\begin{array}{r}\text { Enlarged stages } \\
\text { introduction of innovation }\end{array}$ & $\begin{array}{l}\text { Experimental } \\
\text { implementation }\end{array}$ & $\begin{array}{l}\text { Research and } \\
\text { testing }\end{array}$ & Commercialization \\
\hline Autonomous freight traffic, Plaboning & & +++ & \\
\hline Airless tires, communication between cars & & ++ & \\
\hline Robotics & & + & \\
\hline Business analytics, m-commerce and mobile applications & & & +++ \\
\hline Internet of Things, e-commerce, big-data & & & ++ \\
\hline Omnichannel logistics, drones, ZD printing & +++ & & \\
\hline Intellectual production & ++ & & \\
\hline Circularity of the economy & + & & \\
\hline
\end{tabular}

Omnichannel logistics, drones, and ZD printing have a high level of influence in the innovative process of international trade, which are trends in the miniaturization of the economy and the concept of «smart enterprise».

At present, the miniaturization of electronics is a factor in changes in production for the production of smaller and smaller mechanical, optical and electronic goods and devices. This trend gives impetus to the development of technologies such as automatic identification and data collection, radio frequency identification, the introduction of drones in logistics, reproduction of mini-copies of things using 3D printing, communication between machines, which, in turn, affect elements of the logistics system. In particular, automatic or radio frequency identification allows data to be collected, analyzed and managed during the transport process throughout the supply chain.

As for the concept of «smart enterprise», it is based on the ideas of business intelligence and its conclusions based on Big Dat and Smart

Data, which use methods, technologies, systems, practices, programs, which analyze important business information for better management understanding of market companies and their own business, as well as making timely management decisions, which is the basis for the application of the ominchannel approach.

Omnichannel international trade is impossible without setting up its logistics subsystem, because the customer must receive the goods exactly on time and with the level of service that was guaranteed to him immediately, no matter in which of the channels. Channels of such interaction with customers include offline retail outlets, service terminals, websites, mobile applications, social networks, e-mails and more.

Figure 1 presents the results of the impact of the trend of change from Industry 4.0 innovations in international trade through the impact on consumer behavior and the functioning of business models of enterprises specializing in international trade.

The analysis of the impact of the trend of changes from the innovations of Industry 4.0 is carried out in international trade through the impact on consumer behaviour and the functioning of business models of enterprises indicates the fact that the studied innovations such as online retail, shopping on social networks, marketplaces, going online retailers offline and wholesale services sellers in retail, technologies of reality transformation, artificial intelligence form changes in consumer behaviour and perception of experience, and stores without cash registers, sellers and contactless payments, robots, drones, 3D print, new approaches to advertising and product promotion modify the business models of companies specializing in international trade. Figure 1 shows the trends of changes from innovations of Industry 4.0 in international trade, involving the use of new digital technologies and modern robotics, organization of marketplaces and new approaches to product promotion, reality transformation technology and artificial intelligence, etc., which forms changes in some elements of functional structure. system of international trade and penetrates into its subsystem components. 


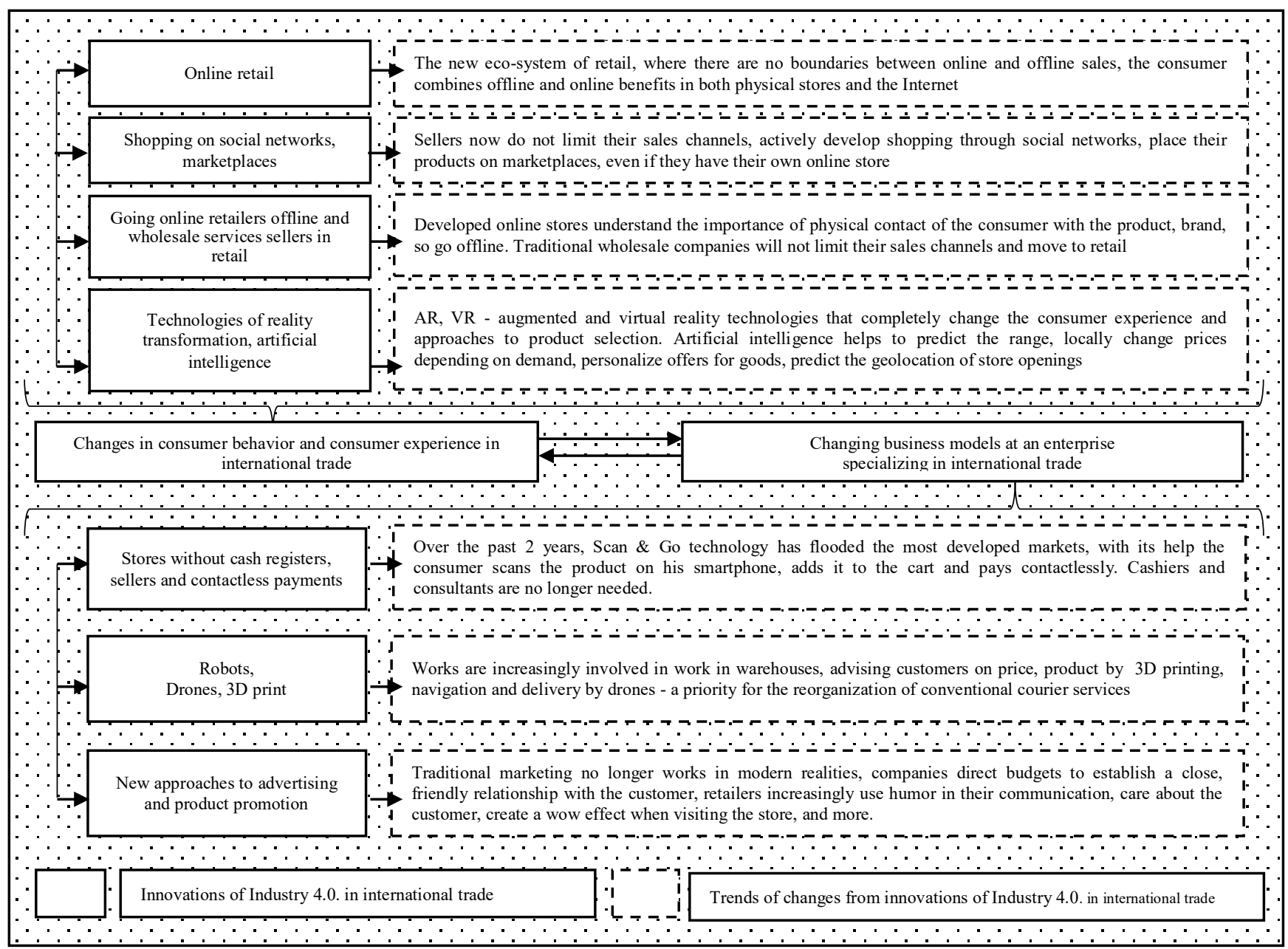

Figure 1 - Impact of the introduction of Industry 4.0 innovations on international trade Source: developed by authors taking into account [38]

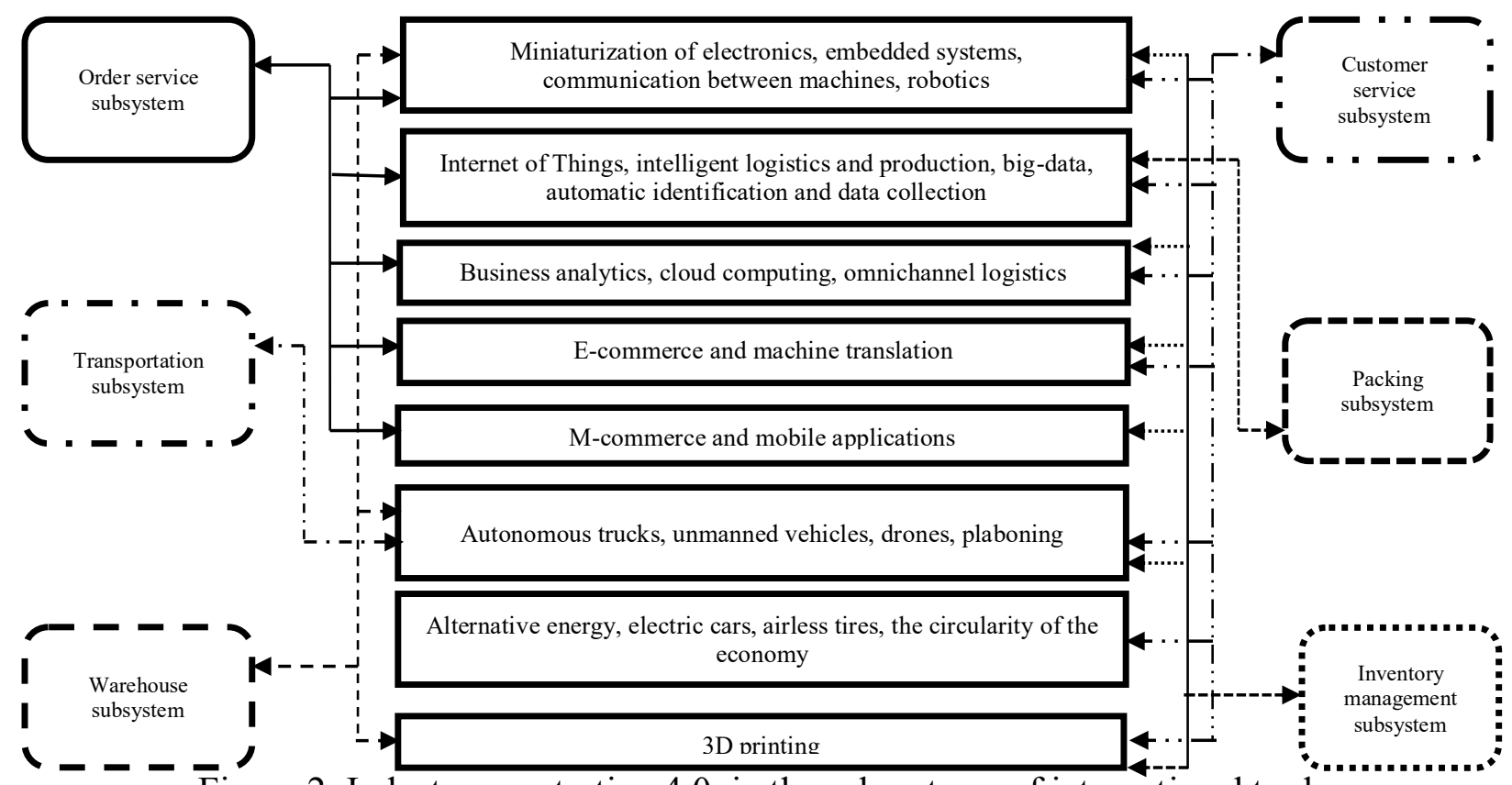

Figure 2. Industry penetration 4.0 . in the subsystems of international trade Source: adapted by the authors to the peculiarities of international trade on the basis of $[1-16,20]$ 
Significant changes in the penetration of Industry

4.0 technologies into international trade subsystems by their types are shown in Figure 2

The proposed ordering scheme in Figure 2 allows the management of companies to solve the problem of «bottlenecks» in the logistics process, helps to increase the efficiency of its individual elements by directing resources to those technologies and implementing those innovations that are relevant to the relevant logistics subsystems. For example, 3D printing technology in the case of opening special mini-factories or $3 \mathrm{D}$ printing can change the characteristics of the inventory management subsystem and the customer service subsystem; by phase separation, 3D printing technology modifies supply logistics, production logistics, sales logistics, processing and recycling logistics; unmanned vehicles have a strong impact on the transportation subsystem, as well as logistics of supply and marketing (etc. according to the scheme).

\subsection{Dronology in the omnichannel approach to international trade}

Omnichannel is a new trend in international trade that is actively developing under the influence of Industry 4.0 and begins with the influence of public opinion on the consumer. In a network with omnichannel, buyers leave $15-30 \%$ more money than in Multi-channel [39]. Upon receiving the signal, the buyer seeks to satisfy his new desire, as quickly as possible, cheaper and better. Customer interaction channels include offline retail outlets, service terminals, websites, mobile applications, social networks, e-mail, and more. In this aspect, omnichannel retail is impossible without a wellestablished logistics system, because the customer must receive the goods exactly on time and with the level of service that was guaranteed to him immediately, no matter in which of the channels.

Thus, the leaders in international trade under the conditions of the omnichannel approach will be those who will master technologies faster than others, who will best set up automation and online sales channels. The basic understanding is that international trade today cannot be only online or only offline.

In the aspect of expanding sales channels and receiving goods in the mode of optimized time, drones, better known as drones, have become relevant. According to Nielsen [40], by 2035 the delivery of goods will be carried out almost realtime (from 30 to 45 minutes after ordering) and with maximum comfort for the buyer by drones. Thus, the current integration of drones into logistics has already increased the level of flexibility and speed of delivery and growth of «last mile» logistics.

American retailer Amazon has been delivering goods in a test mode for more than a year using Prime Air drones. Their goal is to ensure the delivery of goods by drones within 30 minutes. Thus the drone already now carries out delivery in completely independent mode, instead of by means of the remote pilot on the basis of the company. Amazon's Prime Air delivery drones can be expected to deliver packages directly to a warehouse customer in 30 minutes or less for $\$ 1.00$ [38].

Figure 3 shows the significant difference between Amazon Drones and FedEx and UPS costs (with significantly longer delivery times).

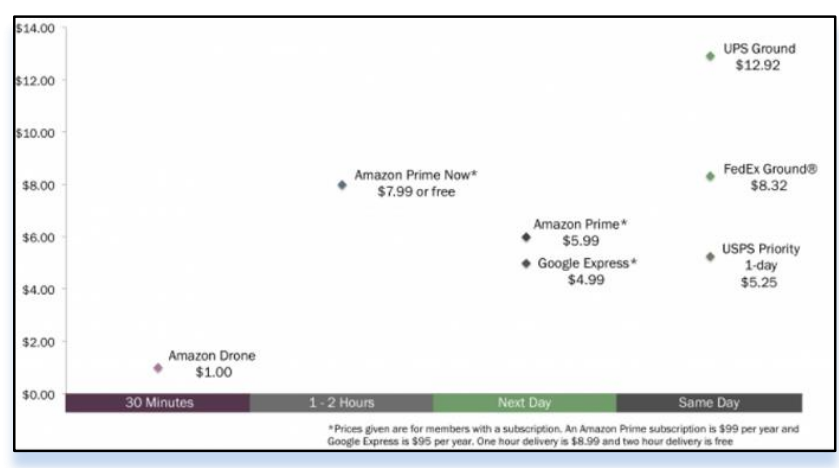

Figure 3. Amazon Drones vs. Current delivery options. An example: price for $5 \mathrm{lb}$ package delivered within 10 miles [41]

Based on Amazon's initial experience, it can be predicted that as the commercial drone market expands, last-mile operators and small package delivery companies could become the ideal logistics business segment for drone take-offs. Due to their characteristics and modern technological limitations of drones (approximately 15 miles and up to 5 pounds), these companies may be the first in the industry to be able to use this technology.

The first logistics companies to be able to adopt drones will drastically reduce transportation costs associated with capital costs for trucks, such as maintenance, fuel, insurance, and more. By doing so, they can have the potential to reduce their shipping costs by about $83 \%$, given that Amazon (a leader in logistics and innovation) can reduce shipping costs to about $\$ 1$ with unmanned technology.

Drones have been used in business and manufacturing since the $1980 \mathrm{~s}$, but in recent years their market share has tended to grow rapidly, increasing and improving their lineup. This is due to the growing demand in various industries, as well as the weakening of legislation on their application 
[42].

One of the last successful UAV launches in the world was a test delivery by a drone from the international logistics company UPS. The tests took place in Florida. The drone was programmed to fly to its chosen destination and launched by a company employee from a launch pad mounted on the roof of the truck. After the parcel was delivered, the drone returned to the truck, which moved to another location, and landed on its roof on its own. According to UPS, delivery using drones will reduce $1.6 \mathrm{~km}$ per day for 66 thousand drivers, which will save up to $\$ 50$ million a year. The drone will receive cargo through a special hatch on the roof of the car, the maximum weight of the package can be $4.5 \mathrm{~kg}$. The drone itself weighs $6.8 \mathrm{~kg}$ and is able to stay in the air for up to 30 minutes and develop a speed of up to $45 \mathrm{~km} / \mathrm{h}$. The car body has a base for recharging drones [43].

The use of drones in the warehouse subsystem of international trade is also relevant. Thus, the operation of large areas of storage involves the constant accounting of those areas that are not yet fully loaded and therefore able to accept new consignments, while video surveillance by drone is a reliable way to solve this problem. Timely collection of all relevant information with its help makes it possible to make the best use of storage capacity and get a significant economic effect.

Delivery by drones, or robot robbers is already actively used in logistics. Transport operators are increasingly immersed in the automation of their processes to save money and save time, because the struggle for timely delivery is already measured in hours, and in some situations even in minutes. Let's analyse the simplest and most logical example of the use of drones - inventory, and more precisely, the control of the accuracy of high-altitude storage miscalculation of pallets. Removing a pallet, scanning, setting up a pallet, moving to the next cell - takes an average of 3 minutes per pallet. If we carry out the same procedure with elements of «innovation» - raising the employee to a height, scanning, moving - we can get an average result of 30 seconds on the pallet. This will involve the storekeeper, the driver of the loading and unloading equipment, the loading and unloading equipment itself, as well as in most cases the operator for the issuance and processing of tasks [43].

The ratio of the cost of the process is presented in Figure 4 in terms of optimizing the cost of maintaining workers through the use of drones.

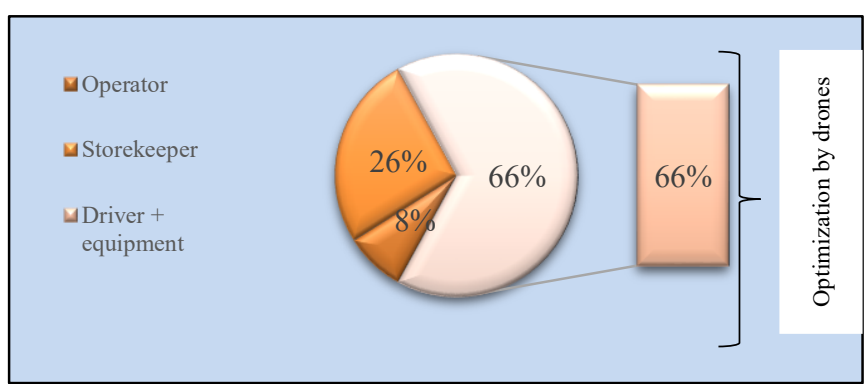

Figure 4. The ratio of the cost and its

optimization by drones. An example: warehousing process

Source: author's calculations

According to Figure 4, the largest cost part is the driver and loading and unloading equipment, which is also the most scarce in the warehouse. The use of drones makes it possible to compensate $66 \%$ of costs by minimizing them.

At the same time, the use of drones is possible not only for the transportation of individual goods, but also for the observation of complex systems, their storage and transportation, which gives a new impetus to the further development of international trade. Equally important is the ability to adapt the internal rules of the warehouse to the peculiarities of the operation of drones, which perform the function of monitoring the entire system. The problem of timely charging of the battery in such conditions is solved quite easily and does not create significant difficulties during operation.

Already, drones provide services in such important areas as food delivery and fast food; transportation of parcels by postal service to the recipient; transportation of medicines and donated blood; provision of emergency medical care in the presence of a threat to human life.

The main advantages of using drones in customer service should be considered the minimum period of time for which such a robot-controlled system is able to deliver the required cargo, as well as the ability to transport them to the area with no infrastructure for other vehicles. The presence of a recovery system saves some energy for further use.

It should also be noted that a drone that has special equipment can literally save lives. In some countries, programs already exist that allow the drone to deliver the defibrillator to where the patient needs to resume heart function.

In addition, the role of drones is becoming more relevant in the context of increasing urbanization processes. Cities cover 2\% of the Earth's surface and are the concentration of more than half of the world's humanity. Increased concern for the environment and concerns about the impact of 
transport, especially urban freight transport, are growing along with population density and increasing urban congestion. However, awareness of the need for sustainable urban development is also growing, and the need for coordination of traffic and logistics is gaining more and more interest, including through drones.

In addition to delivering parcels from Amazon and shooting beautiful videos, unmanned aerial vehicles can perform other tasks. Drones are sent to the hearts of hurricanes to track the evolution of storms, create 3D maps, as well as to more effectively perform search and rescue operations and medicine.

Thus, the use of drones in various fields, especially in logistics, is clearly an innovative solution. Despite the existing protests in society, which try to slow down the development of technologies that will completely replace human labor in the future, drone logistics requires the introduction of high-tech tools to improve and optimize the integrated system.

The optimization of supply chains based on drones provides an opportunity to some extent to solve the problem of «last mile» according to the concept of McKinsey [1]. The last link is the most expensive part of the logistics supply chain. Its optimization can not only increase revenues, but also improve the overall reputation of the company through quality and fast customer service «, and this will certainly contribute to innovative solutions in logistics, including drones. It is estimated that reducing logistics by 20 minutes saves up to 2 million euros per year (or 4 million euros per year in Paris).

As the commercial drone market expands, lastmile operators and small package delivery companies can become an ideal segment of the logistics business for drone take-off. Due to their characteristics and modern technological limitations of drones (approximately 15 miles and up to 5 pounds), these companies may be the first in the industry to be able to use this technology.

The results of the report «Last link: quantification» calculated using the model «Total cost of the last link» McKinsey, which allows developers, investors and tenants to quantify the cost of delivery of the last link, conducted in some European countries in 2017 and 2018, showed that consumers' expectations regarding the speed of delivery are growing (see Figure 5).

It is worth noting that the consumer not only wants the speed of delivery of goods, but also in case of dissatisfaction with this product, seeks to return the money just as quickly to be able to place a new order immediately. Such an applied situation is also solved by drone logistics.

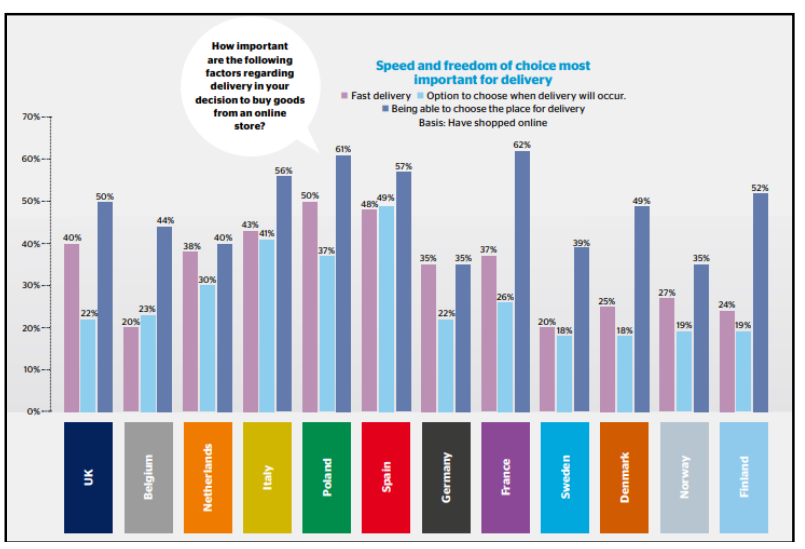

Figure 5. Speed and freedom of choice most important for delivery, 2020 [44]

Yes, drones not only provide a real opportunity to reduce return cycles, but also inconvenience when you need to go to the post office and deliver your goods. The drone without excessive loads can be sent to pick up the damaged goods and return them to the sender. Returns can be processed while the drone is still on the road. Faster turnover means faster resolution of return requirements, so the consumer returns to the case, rather than waiting for the order to be verified and confirmed. This effect of drone logistics helps to eliminate barriers to ecommerce and brings e-commerce to new horizons.

At the same time, the large-scale introduction of drones, as well as information technology in general, exacerbates the issue of replacing workers in entire industries with artificial intelligence and robots, which is a typical risk of the 4th industrial revolution, namely replacing workers with artificial intelligence systems and robots. labor market. As you know, many companies in this field are now seriously considering the possibility of delivering parcels in the cities by drones, and the transportation of luggage within the city and between logistics centers - unmanned vehicles and trucks.

So, in 2009, the University of North Dakota became the first university to introduce a specialty in the operation of unmanned aerial vehicles, according to Forbes. At least 30 other universities are currently offering such diplomas, including Christie's Corps A\&M University of Texas, one of six approved drone research and testing sites. Students learn to develop technologies to create and improve drones, control them and evaluate their performance. Graduates with such diplomas are in great demand, and the need for them will continue to grow as the development of dronology [45]. 


\subsection{D Printing: the impact of additive manufacturing on international trade}

$3 \mathrm{D}$ printing technologies are gaining popularity with the advent of Industry 4.0. At present, additive 3D printers are widely used in mechanical engineering, engineering and industry for fast printing of test parts and testing of products before serial production. In the construction, architectural and advertising spheres, architectural, construction and exhibition models are actively printed on 3D printers. 3D printing can also be used for mass production of miniature products.

Representatives of European business already see good prospects in 3D and for the most part believe that they will be useful for their companies in the future. This is evidenced by the results of a study conducted by experts of the digital association Bitkom [46]. Data from surveys of enterprises with more than 100 employees showed the attitude to 3D printing in the following context: $3 \mathrm{D}$ can be an effective tool against disruptions in supply chains $38 \%$ of respondents; will improve the flexibility of production processes $-43 \%$; $3 \mathrm{D}$ is indispensable for the manufacture of individual and original products - $31 \%$; will save money $-21 \%$; reduce the level of stocks - 19\%; increase the freedom to create a design and help reduce the impact on the environment - 9\%; will help reduce the number of production operations - 7\%; will improve the properties of the product - 3\%; 3D printing has no advantages - 5\%. Analysts of the association also reported that in such a technologically advanced country as Germany, $44 \%$ of industrial companies with more than 100 employees already use 3D printing in one way or another. Another $20 \%$ plan to introduce this technology in the near future.

Making parts on a 3D printer is essentially a copy of an existing object and its layered formation of plastic. 3D printing has a number of advantages:

1. Relative simplicity. There are a number of 3D editors (OpenSCAD, 3D Max) that allow you to create models suitable for printing.

2. Speed of execution. Making parts on a 3D printer does not take much time, depending on the size, but usually within a day.

3. Cost. In general, it depends on the type of printing and the quality of consumables. 3D printing of plastic parts or consumables is statistically more profitable than buying the original.

4. Originality and strict compliance. Many are familiar with the annoying breakdown of one part of the unit, which is sold only in the assembly. 3D printing of machine parts and equipment allows you to reproduce a specific required element on strictly defined parameters, which is especially important when designing or restoring mechanisms, parts of which are very difficult to find.

5. Quality. The parts reproduced by the printer at the correct density do not concede to plastic originals.

However, 3D printing is not a super modern technology. It was invented before the advent of the Internet. For example, in 1981, Hideo Kodama of the Nagoya Industrial Research Institute in Japan invented a rapid prototyping system using photopolymers. The model was created by overlaying layers. And only three years later, in 1984, there was a real breakthrough in this area. Charles Hull, an American researcher and founder of 3D Systems, invented the stereolithography apparatus (or SLA, which stands for Stereolithography Apparatus), which made it possible to print 3D objects whose models were predesigned on a computer. This development, in the form of the first full-fledged commercial model SLA-1, which was released in 1987, was a real revolution among inventors, as it allowed them to test their prototypes without huge prior investment in production. And since the early 90's 3D Systems has established mass production of SLA. At the same time, another startup, DTM, received a patent for selective laser sintering technology created by Carl Deckard of the University of Texas. Instead of liquid polymer, metal powder was used in this technology. Shortly afterwards, Stratasys, under the leadership of Scott Crump, developed a newer technology - surfacing modeling. This is when three-dimensional objects are created by sequentially applying layers of material that replicate the contours of a digital model. Usually thermoplastics are used as a material, which are loaded into the printer in the form of special spools of thread or rods. By the way, the vast majority of modern basic 3D printers use this method [47].

Parts made with a 3D printer are also often stronger and lighter than traditionally made parts. Although this technology is still in its infancy, it already produces many products. Not only individual parts are produced, but more and more often the final products. Examples are furniture, prostheses, cars, planes and car parts, and even whole cars and prefabricated parts of the house.

In the past, the costs associated with the introduction and use of new technologies in industrial production have decreased significantly over time. Therefore, from a perspective, it is plausible that technological development makes the use of $3 \mathrm{D}$ printers also attractive for mass production, which can significantly modify modern international trade. 
Table 3 presents the development of 3D printing technology in terms of impact on production with a projection on the types of goods sold by trade. These five industries have been the largest investors in 3D printers for most of the last decade. Although medical and dental devices and the aerospace industry make the most use of $3 \mathrm{D}$ printers and printing services, they are smaller industries than industrial equipment, automotive and consumer products, but account for the lion's share of global investment in $3 \mathrm{D}$ printers.

Table 3. Areas of application and consequences of the introduction of three-dimensional printing, 2016

\begin{tabular}{|c|c|c|c|}
\hline Areas of application & $\begin{array}{l}\text { Share in sales of } \\
\text { 3D printers }\end{array}$ & Examples of what has been done & Impact on production \\
\hline $\begin{array}{l}\text { Industrial } \\
\text { equipment }\end{array}$ & $19 \%$ & Manufacture of tools such as jigs and fasteners & $\begin{array}{l}\text { Less time consuming / cheaper to produce (shorter } \\
\text { lead time) }\end{array}$ \\
\hline Aerospace & $18 \%$ & Geometrically complex and light details & $\begin{array}{l}\text { Less inventory, and sometimes faster (so much } \\
\text { cheaper) to produce }\end{array}$ \\
\hline Car & $15 \%$ & $\begin{array}{c}\text { Functional prototypes, small and complex parts for } \\
\text { luxury and vintage cars. Mainly non-mass } \\
\text { production of specific tools and parts and for } \\
\text { prototyping. }\end{array}$ & $\begin{array}{l}\text { Cut or even eliminate tool, welding and whole } \\
\text { assembly lines. Tools for design and manufacture } \\
\text { become necessary }\end{array}$ \\
\hline Consumer goods & $13 \%$ & $\begin{array}{c}\text { Microelectromechanical systems, microwave } \\
\text { circuits made on paper substrates, radio frequency } \\
\text { identification devices inside solid metal objects } \\
\text { (RFID), three-dimensional based on polymer, } \\
\text { grippers }\end{array}$ & $\begin{array}{l}\text { Easier adaptation to specific development processes, } \\
\text { acceleration of the design process, functional } \\
\text { integration of a number of different electronic } \\
\text { devices in only one product, functional prototypes, } \\
\text { spare parts made to order }\end{array}$ \\
\hline $\begin{array}{l}\text { Medical and dental } \\
\text { devices }\end{array}$ & $11 \%$ & $\begin{array}{l}\text { Thighs, knees, tooth straighteners, hearing aids, } \\
\text { digital dentures, etc. }\end{array}$ & $\begin{array}{c}\text { Reduced processing time, digitization of the } \\
\text { production process, easy reproduction of production } \\
\text { properties. }\end{array}$ \\
\hline
\end{tabular}

It is difficult to predict the future share of 3D printed goods and services in production worldwide. There is no data on the cost of goods currently produced with the help of 3D printers and related services (maintenance, operator training, etc.). It is also unknown whether this technology will promote mass production on a large scale. However, the latest technological advances show that high-speed and, consequently, mass production with 3D printers is becoming a reality. Advanced $3 \mathrm{D}$ printing technology, called high-speed sintering, can produce up to 100,000 (smaller) components per day.

According to Wohlers' annual 3D printing report, [48] companies worldwide spent \$ 6.6 billion on 3D printers and related services in 2016. By comparison, private investment in traditional machines in the world in the same year was \$ 6.7 billion, which is actually as much as private spending on $3 \mathrm{D}$ printers. This indicates that the number of goods manufactured using 3D printers and the cost of related services is currently only a fraction of total world production of goods and services. The scenario forecast of development of 3D printing for 2016 presented by him is actual.

It is assumed that the performance of a threedimensional printer is equal to the performance of a traditional machine of the same size, the share of 3D in world GDP is less than $0.1 \%$, or less than $0.7 \%$ of total world production. However, the role of 3D printing in the economy will grow rapidly. The annual growth rate of investment in 3D printing was $29 \%$ over the last five years, compared to an average of $9.7 \%$ for the overall growth of investment in traditional machines. To see how the share of 3D production can develop, we take as a starting point nominal investments in 2016 (6700 billion US dollars and 6.6 billion US dollars) and consider them as appropriate capital reserves for traditional machines and 3D printers. Assuming that the annual difference in investment growth continues to average $19 \%$ over the next decades, the stock of 3D printers will be equal to the stock of capital and, consequently, the production of traditional machines in 2060 (see Figure 6).

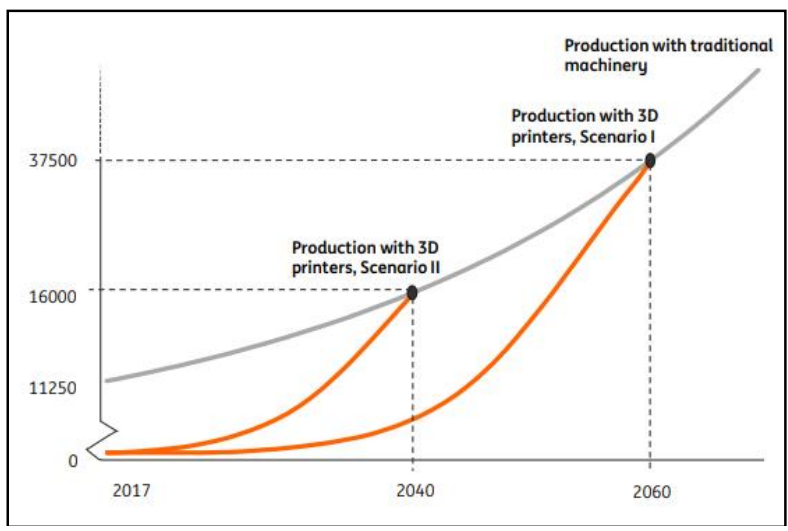

Figure 6. Conditional scenario of the impact of 3D printing on world production (billion USD) [48] 
Thus, according to Figure 6, the following is selected. The scenario assumes that the current difference in investment growth in 3D printers and traditional machines by 19 points continues, so that the fixed capital and production of 3D printers will be equal to traditional machines in 2060 .

Thus, 3D printing technology in the future can change the model of existing supply chains in the international trade system, namely:

1) printing of spare parts under the order. Companies that distribute technically complex goods are forced to keep a large number of spare parts in stock for proper service and compliance with their warranty obligations. However, some components are either rarely used or never. Excess stocks in warehouses sometimes exceed $20 \%$ of their total, which is not only an expensive pleasure for companies, but also creates inefficient logistics chains. Thanks to 3D printing technology, companies can solve the problem of physical retention of spare parts in warehouses. They can print spare parts to order when needed and deliver them quickly to the consumer. For sufficient territorial coverage, logistics providers can create dense networks of 3D printers. This is how physical goods are replaced by information, in practice it looks like the creation of a virtual database of all necessary parameters of goods, and this can be called a «virtual warehouse»;

2) individual production of goods or spare parts. 3D printing can be a source of competitive advantage for the organization if the customer needs a high level of customization of the order. Companies can create 3D printing centers, each of which will act as a separate micro-factory. Products manufactured by such micro-factories can be manufactured under the company's own OEM brand. Already today, a similar approach is used in the medical industry, which combines traditional production methods with 3D printing technology. The logistics operator must ensure fast, safe and reliable delivery of spare parts to the right place just when it is needed;

3) postponement of production operations. This concept involves the manufacture of a «generic product» by the manufacturer, which can be modified at a later stage before the final delivery to the customer. The use of 3D-printing technology makes it possible to move to a higher level of product customization. Yes, companies can offer their customers a wide range of options for individual customization of the final product design, material, shape, size, packaging, product functionality, etc ;

4) «end of runway services». This is a logistical approach to locating a warehouse with critical spare parts in close proximity to important airports. The idea is that the customer can order the required number of spare parts immediately before sending the main batch of goods. In order to produce the required spare part in the shortest possible time, the 3D mini-factory is located close to the airport. Thus, the customer can receive a critical spare part the day after placing the order. Currently, a similar concept is used in the integrated logistics concept of UPS and Fast Radius;

5) 3D printing shops. In theory, companies could replace some service points or shops with 3D minifactories. They can look something like copy centers or points for printing images or advertising products, in which the customer only needs to bring a file with information and get the desired product. A 3D printing shop can offer customers information with a prototype of the desired product, which the consumer prints himself. This is the most difficult concept in terms of implementation, as it requires, firstly, the development of 3D printing technology (the existence of a wide range of printing materials, reducing the cost of services), secondly, special knowledge and training of customers, thirdly, unclear how companies will protect their product from «pirated» copying [20].

Today, the trend of increasing the use of 3D printers in production is affecting the replacement of human labor with capital and technology. Thus, low-wage countries are losing their international competitiveness. Outsourcing of production processes to these countries is becoming less attractive for advanced industrial countries. This means that in industrialized countries one should expect a tendency to attract finance. This trend is exacerbated by the fact that production at the consumer's place makes it possible to minimize transport costs, both by transporting the final product to the consumer, and pre-transportation of individual parts and preliminary work to the place of production.

One of the aspects of increasing the pace of trade is the regionalization of production, caused by a decrease in imports of materials, as there is a possibility of their reproduction in $3 \mathrm{D}$ printing. Yes, the parts are not made by suppliers from abroad, but with the help of 3D-printing technology at the place of production. This reduces the cost of production and turnover (consumption of materials is lower, and transport costs are excluded). The described property of the production technology of 3Dprinting technology will lead to an increase in crossborder trade in raw materials needed for the production of $3 \mathrm{D}$ printers, and to attract investment 
in the development of this segment of production and further trade. From an environmental point of view, this is a positive development: less global trade means less energy consumption, which reduces environmental pollution [49].

The undoubted advantage of a $3 \mathrm{D}$ printer is the ability to do almost anything with minimal cost. But due to this, the «boundary» between producer and consumer becomes more blurred. Producing products from well-known manufacturers «at home» has never been so simple and affordable.

The risks of intellectual property infringement are more related to the commercial use of 3D printing. The main group of risk, ie intellectual property, the rights to which may be infringed in the first place, are industrial designs, copyright and trademarks. And the easier it is to reproduce them on a $3 \mathrm{D}$ printer, the higher the risk.

For example, simple designs protected by industrial design patents can not only be simply printed on a $3 \mathrm{D}$ printer, but by changing some details in the design without changing the functional purpose, attempts can be made to circumvent the patent. The vulnerability of copyrights and trademarks in this case is even higher, because they usually lack a 3D component. For inventions and utility models, the $3 \mathrm{D}$ printer poses the least risk, but it will all depend on the development of this technology.

In general, today we can talk about the possible consequences of $3 \mathrm{D}$ printing technology on the field of intellectual property [50]:

1. 3D printing will certainly affect companies' strategies for the production of original goods, in particular, increase technical protection against copying original goods with a 3D printer, as well as the development of new approaches and methods to combat counterfeiting.

2. The scope of licensing of intellectual property is changing. Yes, it is quite possible to license the production of products on a $3 \mathrm{D}$ printer. However, this new type of licensing can not be called a simple issue, because in this regard there are a number of additional questions regarding consumer protection, liability for product defects, the transfer together with the license and some know-how, and so on

3. Popularization of 3D printing will definitely lead to the emergence of sites (online services, fileexchangers) for the exchange of files with 3D models of products or that allow the download of such files. The balance of interests between copyright protection for the $3 \mathrm{D}$ file and the intellectual property rights of the product manufacturer has yet to be found both by improving legislation and by law enforcement practice.
4. The emergence and spread of technologies that allow you to quickly convert images to 3D models. For example, back in 2012, Autodesk introduced the 123D Catch program, which translates ordinary images into 3D models.

5. The issue of consumer protection is also relevant today, in particular, in terms of causing harm to health. The answer to the question of who is to blame: the manufacturer of the original product or the person who wrote / created the file for the 3D model, or the manufacturer of the $3 \mathrm{D}$ printer, or the operator of the $3 \mathrm{D}$ printer, or the manufacturer of the material - remains more than open and devoid of sufficient regulation.

\section{Discussion}

Thus, today there is a trend of gradual serious changes in international trade based on the destructive innovations of Industry 4.0. Increasing digitalization, omnichannel and miniaturization of technology, the emergence of new methods of organizing subsystems of international trade lead to a reduction in enterprise costs. Promising innovations that are now developing most progressively are, of course, the use of drones in logistics and the widespread introduction of 3D printing in the subsystems of international trade. Their use creates many new opportunities for companies and changes their business models, creates significant potential for cost savings and requires the search for staff with new qualifications. Undoubtedly, the innovative concepts of the use of drones in logistics and the introduction of 3D printing have a catalytic effect on accelerating the development of international trade subsystems in the context of Industry 4.0.

In the context of consumer sentiment to accelerate service processes, it is proposed to optimize the principles of international trade on the basis of the described catalytic effect of drone logistics and 3D printing by developing strategic actions to manage supply chains and stocks based on the concept of «Last Mile» McKinsey. It is on its basis that we have formed the possibility of overcoming the «last mile» at the base of the catalytic effect of drone logistics and 3D printing on international trade, which is summarized in Figure 7.

Currently, the optimization of the principles of international trade in terms of Industry 4.0 based on the concept of «Last Mile» by McKinsey provides:

1. Maximum full realization of consumer expectations in delivery (which can be solved within the framework of dronology) and conformity of goods (reproduction of goods by 3D printing 
technology (where applicable).) It is necessary to always apply their observations of customers and market research results to improve logistics chains and stockpiling.

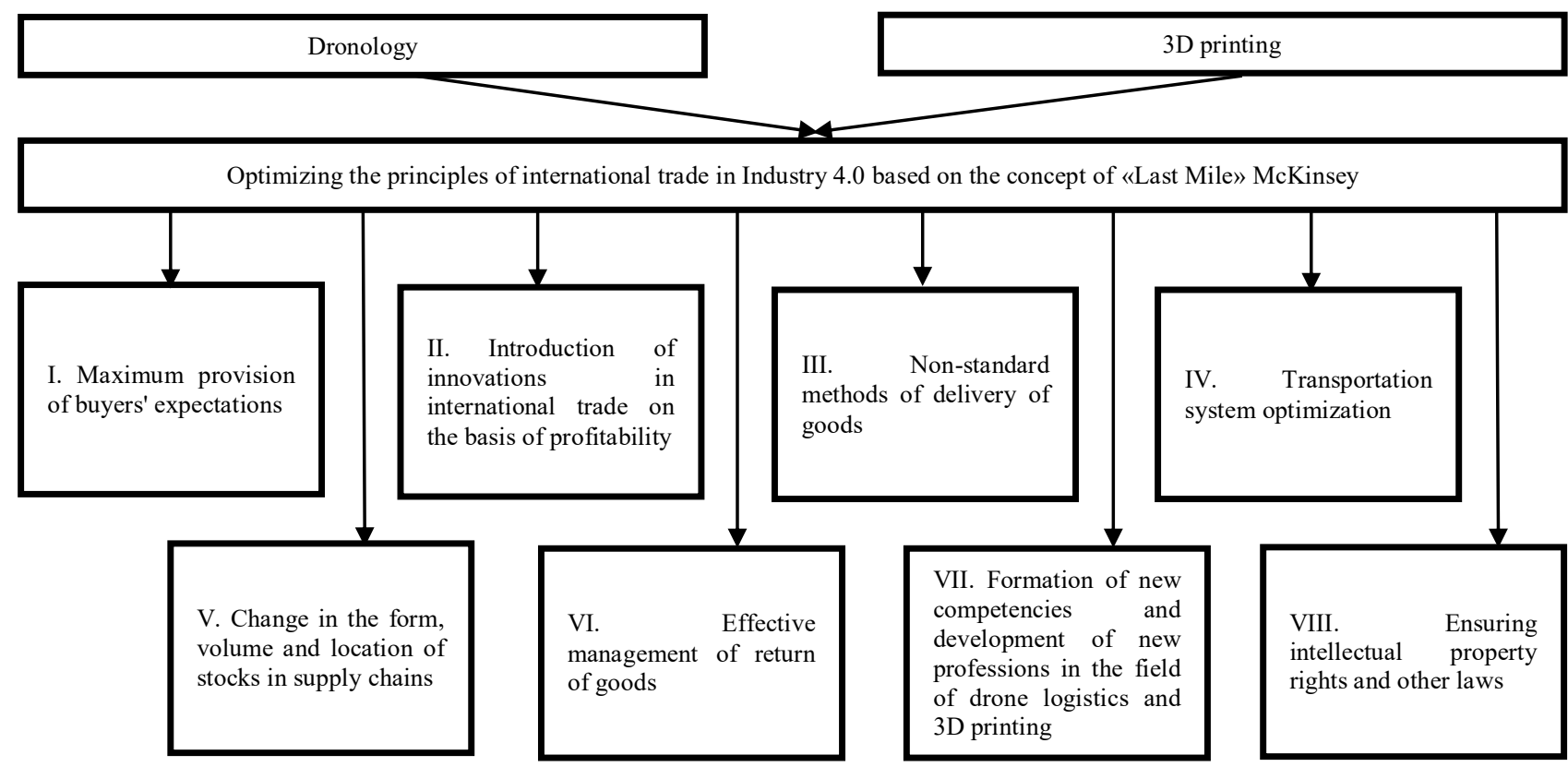

Figure 7. Optimization of the principles of international trade in Industry 4.0 based on the concept of «Last Mile» McKinsey under the influence of drone logistics and 3D printing Source: generalization of authors' research

2. Introduction of innovations in international trade on the basis of profitability, for example by solving the dilemma of minimizing their value. In this case, we must strive to change customer expectations to increase the profitability of delivery «last mile». You can offer customers to make purchases that can be delivered by drones or reproduced on a 3D printer.3. Non-standard delivery methods (for example, based on drones), which will make it possible to instantly fulfill orders.

4. Optimize the transportation system to overcome the problem of the last mile. It is at this stage that the cost of delivery changes dramatically, and this is where innovation should be introduced, but replacing traditional delivery methods, care must be taken to improve security and cargo tracking systems so that quality goods are delivered to your customer. Therefore, the development of technology in this area is of great importance.

5. Change of forms, volumes and place of stocks in supply chains on the basis of their reproduction by the method of additive production - 3D printing. Control over stocks of goods at all points will allow you to organize a cost-effective delivery to the buyer from the nearest point, and thus successfully solve the problem of «last mile».

6. Effectively manage returns based on drone logistics. It is advisable to try to make return management one of the tools to overcome the «last mile»: create a convenient return service for customers and establish a smooth infusion of goods returned to the flow of supply.

7. Formation of new competencies and development of new professions in the field of drone logistics and 3D printing. Timely development of new professions will overcome structural unemployment and accelerate the introduction of these innovations in the subsystems of international trade.

8. Ensuring intellectual property rights and other laws. It will promote the development of a new segment of the international trade market - trade in licenses and patents for goods while combating industrial plagiarism and combating violations in the field of reproduction of copies on $3 \mathrm{D}$ printers.

\section{Conclusion}

Thus, such innovations of Industry 4.0 as drone logistics and 3D printing are catalysts for the growth of international trade through the acquisition of profitability and efficiency of its implementation in the formation of modern economic systems. The level of influence of the catalytic effect of each of them depends on the effectiveness of the organization of subsystems of international trade through omnichannel: the availability of stocks in the right place at the right time; development of a flexible supply system in which stocks are as close 
as possible to the potential customer; creating delivery methods that are convenient for buyers and not expensive for the seller; implementation of a well-thought-out return system and customer retention strategy.

The findings serve as a basis for future research by authors in this field to study the effects of largescale introduction of drones and 3D printing on the formation of a new labor market and the replacement of certain professions with artificial intelligence in international trade in goods and services.

\section{References:}

[1] Industry 4.0: How to navigate digitization of the manufacturing sector McKinsey Digital (2015). Retrieved from https://www.mckinsey.de/files/mck_industry_4 0 report.pdf

[2] Barreto L., Amaral A., Pereira T. (2017). Industry 4.0 implications in logistics: an overview. Procedia Manufacturing, 13. pp. 1245-1252.

[3] Wollschlaeger M., Sauter T., Jasperneite J (2017). The Future of Industrial Communication: Automation Networks in the Era of the Internet of Things and Industry $4.0 /$ IEEE Industrial Electronics Magazine.Volume: 11, Issue: 1, March 2017. pp. 17-27.

[4] Josef Börcsök, Michael Schwarz, Muhammad Ikram Hafiz, Mohamed Abdelawwad, Ahmed Alsuleiman, Safe Position Detection Based on Safety System-on-Chip (SSoC) for Wireless IoT Application, International Journal of Circuits, Systems and Signal Processing, Volume 14, 2020, pp. 1040-1046.

[5] Elda Cina, Hiba Tabbara, Esmerald Aliaj. Data Compression and Protection Through Representation With Combinations and Spiral Path, International Journal of Circuits, Systems and Signal Processing, Volume 14, 2020, pp. 942-951.

[6] Yepifanova I., Dzhedzhula V. Modelling of Potential Level of Industrial Enterprises. WSEAS Transactions on Environment and Development, Vol. 17, 2021, pp. 556-565.

[7] Duong Oesterreich T., Teuteberg F. (2016). Understanding the implications of digitisation and automation in the context of Industry 4.0: A triangulation approach and elements of a research agenda for the construction industry. Computers in Industry, 83, pp. 121-139.

[8] Scalabre O. (2015). Embracing Industry 4.0 and Rediscovering Growth. BCG. Retrieved from:

https://www.bcg.com/ capabilities/operations/embracing-industry-4.0rediscovering-growth.aspx

[9] Stock T., Seliger G (2016). Opportunities of Sustainable Manufacturing in Industry 4.0. Procedia CIRP, 40, pp. 536-541.

[10] Industry 4.0 - Opportunities and Challenges of the Industrial Internet / R. Geissbauer, S. Schrauf, V. Koch, S. Kuge. PricewaterhouseCoopers Aktiengesellschaft Wirtschaftsprüfungsgesellschaft, December 2014. 52 p.

[11] Przemysław Zawadzki, Krzysztof Zywicki (2016). Smart product design and production control for effective mass customization in the Industry 4.0 concept. Management and Production Engineering Review, 7. No 3, pp. 105-112.

[12] Xiaomin Li, Di Li, Jiafu Wan, Athanasios V. Vasilakos (2017). A review of industrial wireless networks in the context of Industry 4.0. Wireless Networks, 23 (1), pp. 23-41.

[13] Gilchrist A. (2016). Industry 4.0: The Industrial Internet of Things. Apress. - $250 \mathrm{p}$.

[14] Industrie 4.0 in a Global Context Strategies for Cooperating with International Partners / $\mathrm{H}$. Kagermann, R. Anderl, J. Gausemeier, G. Schuh, W. Wahlster (Eds.); acatech STUDY. Herbert Utz Verlag GmbH, 2016. 74 p.

[15] Industry 4.0. The Future of Productivity and Growth in Manufacturing Industries / M. Rubmann, M. Lorenz, P. Gerbert, M. Waldner et. al. Boston Consulting Group. April 2015. 20 p.

[16] [16] Hermann M., Pentek T. and Otto B. (2016) Design Principles for Industrie 4.0 Scenarios. Proceedings of 49th Hawaii International Conference on System Sciences HICSS, Koloa, 5-8 January 2016, 3928-3937. https://doi.org/10.1109/HICSS.2016.488

[17] [17] Chabot D. (2018). Trends in Drone Research and Applications as the Journal of Unmanned Vehicle Systems Turns Five. Journal of Unmanned Vehicle Systems, 6 (1), pp. $6-15$

[18] [18] Roca-Riu M., Menendez M. (2019). Logistic deliveries with drones. State of the art of practice and research. Logistic deliveries with drones. State of the art of practice and research. 000342823

[19] Bass J. (2019). Leveraging Drones for Delivery: Our Vision to Improve Safety, the Environment,and Customer Service, paper presented at the Transportation Research Board 98th Annual Meeting. 
[20] Petrunya, Y., Pasichnyk, T. (2018). Impact of modern technologies on logistics and supply chain management. Marketing and Management of Innovations, 1, pp. 130-139.

[21] Figliozzi, M., Tucker, C., Polikakhina, P. (2018). Drone Deliveries Logistics, Efficiency, Safety and Last Mile Trade-offs. Proceedings 7th International Conference on Information Systems, Logistics and Supply Chain, ILS Conference 2018, July 8-11, Lyon, France.

[22] Wang K. (2016). Logistics 4.0 Solution New Challenges and Opportunities, Proceedings of the 6th International Workshop of Advanced Manufacturing and Automation, Manchester, UK, pp. 68-74.

[23] Winkelhaus S., Grosse E. (2020) Logistics 4.0: a systematic review towards a new logistics system. International Journal of Production Research, 58(1), pp. 18-43.

[24] Wawrla L., Maghazei O., Netland T. (2019) Applications of drones in warehouse operations. Whitepaper. ETH Zurich, DMTEC, Chair of Production and Operations Management.

[25] Cleland-Huang J., Vierhauser M., Bayley S. (2018). Dronology: An Incubator for CyberPhysical System Research. ICSE-NIER'18: Proceedings of the 40th International Conference on Software Engineering: New Ideas and Emerging Results, pp. 109-112.

[26] Eckstein M. (2016). Let's look closer at 3D printing and IP issues. Inside Counsel Magazine. Retrieved from http://www.insidecounsel.com/2016/02/09/letslook-closer-at-3d-printingand-ipissues? slreturn $=1461486797$

[27] Abeliansky Ana L., Martinez-Zarzoso I, Prettner, K. (2015). The impact of 3D printing on trade and FDI, Center for European, Governance and Economic Development Research Discussion Papers 262, University of Goettingen, Department of Economics.

[28] Leering R. (2017). 3D printing: a threat to global trade. Economic and Financial Analysis Division, ING Bank NV, Amsterdam.

[29] Moreau C. (2021). The state of 3D Printig. 2021 Edition. Sculpteo, p. 15

[30] Dumanska, I. (2021). Quality assessment of business strategy in international trade: indicators and parameters. Baltic Journal of Economic Studies, 7 (2), 57-64. https://doi.org/10.30525/2256-0742/2021-7-257-64
[31] Brand Finance Global 500 (2019). Retrieved from https://brandfinance.com/images/ upload/global_500_2019_locked_1.pdf

[32] Iankovets T. (2019). Digital technologies in increasing brands value. Herald of Kyiv National University of Trade and Economics, 4(126), pp. 85-100.

[33] Dumanska I., Hrytsyna L., Kharun O., Matviiets O. (2021) E-commerce and Mcommerce as Global Trends of International Trade Caused by the Covid-19 Pandemic. WSEAS Transactions on Environment and Development, 17. No 38. pp. 386-397.

[34] Deloitte: Global powers of retailing 2018. Transformative change, reinvigorated commerce. Retrieved from https://www2.deloitte.com/content/dam/Deloitt e/global/Documents/consumerindustrialproducts/cip-2018-global-powersretailing.pdf

[35] Voynarenko M., Hurochkina V., Sushkova O., Yepifanova I. (2020). Beneficial ownership chain and its evaluation arrangement. Estudios de Economia Aplicada, 38, (4). doi: http://dx.doi.org/10.25115/eea.v38i4.3991

[36] Mamatova T.V., Chykarenko I.A., Moroz E.G., Yepifanova I.Y., Kudlaieva N.V. (2020) Management of enterprises and organizations under the conditions of sustainable development. International Journal of Management, 11(4), pp. 151-159.

[37] Voynarenko M., Dzhedzhula V., Yepifanova, I. (2016). Modelling the process of making decisions on sources of financing of innovation activity. Economic Annals-XXI, 160(7-8),126-129.

[38] Cristinel V., Cercel M. (2015) Innovation in retail: impact on creating a positive experience when buying fashion products. Amfiteatru Economic, 39, pp. 583-599.

[39] Omnichannel: to be or not to be? A new era of retail. Retrieved from http://workabox.ua/kitchen/sale/omnkanalnostbuti-chi-ne-buti-nova-epokha-rozdrbno-torgvl/

[40] Lishchuk Y. What will be FMCG-retail of the future, Nielsen Ukraine. June 2018. Retrieved from https://rau.ua/personalii/yurij-lishhuknielsen-ukraina/

[41] Keeney T.(2015). Amazon Drones Could Deliver a Package in Under Thirty Minutes for Less Than One Dollar. Retrieved from https://ark-invest.com/articles/analystresearch/amazon-drone-delivery

[42] Vasylkivskyi D., Matiukh S., Dziuba M. (2019). International logistics development in the globalization of the world economy. Actual 
problems of modern science: Monograph / edited by Skyba M., Topolinski T., Musial J., Polishchuk O. Bydgoszcz: UTP, pp. 35-43.

[43] Dumanska I. (2021). Drons in logistics: digital technologies against the covid-19 pandemic. Proceedings 4th International scientificpractical conference «Modern trends in the development of financial and innovationinvestment processes in Ukraine», Conference March 12, Vinnytsia, Ukraine. Retrieved from https://conferences.vntu.edu.ua/index.php/fiip/f iip2021/paper/view/11368/9485

[44] E-commerce in Europe 2020. PostNord Report. Retrieved from https://www.postnord.se/siteassets/pdf/rapporte r/e-commerce-in-europe-2020.pdf

[45] Golinata A. (2017). Three exotic specialties obtained in American universities: Voice of America. February. Retrieved from https://ukrainian.voanews.com/a/tryekzotychni-spetsialnosti-v-amerykanskykhuniversytetakh/3742569.html

[46] Reserch: European Business believs in the prospects of 3D printing: Logist.FM. April, $2020 . \quad$ Retrieved from https://logist.fm/news/doslidzhennyaievropeyskiy-biznes-virit-u-perspektivi-3ddruku

[47] How and why invented 3D printing: FTR. Retrieved from http://thefuture.news/3dprinting

[48] Wohlers Report 2017: 3D Printing and Additive Manufacturing State of the Industry, Annual Worldwide Progress Report: Chapters titles: The Middle East, and other countries. 22 ed. FORT COLLINS, Colorado, USA : Wohlers Associates, Inc., 2017. 344 p.

[49] Petersen T. (2019). How 3D Printing Technology Could Change World Trade: GED. Retrieved from https:/gedproject.de/digitization-and-innovation/how-3dprinting-technology-could-change-world-trade/

[50] 3D Printing and Intellectual Property Law: Key Considerations. April, 2015. Retrieved from http://www.qlegal.qmul.ac.uk/docs/157017.pdf.

\section{Contribution of individual authors to the creation of a scientific article (ghostwriting policy)}

Ilona Dumanska was formed of research ideas, made general guidance.

Dmytro Vasylkivskyi wrote the introductory and problem formulation of the article.
Igor Zhurba was responsible for Literature review and statistical material.

Yana Pukhalska has implemented the methodological approach.

Olga Matviiets organized translation and wrote conclusion.

Andriy Goncharuk was responsible for the analytical part of the article.

\section{Sources of funding for research presented in a scientific article or scientific article itself \\ Personal funds of the authors}

\section{Creative Commons Attribution \\ License 4.0 (Attribution 4.0 \\ International , CC BY 4.0)}

This article is published under the terms of the Creative Commons Attribution License 4.0

https://creativecommons.org/licenses/by/4.0/deed.en US 